\title{
TRANSFORMASI BENTUK MAKAM RAJA-RAJA TANETE DARI ABAD KE-17 HINGGA ABAD KE-20
}

\author{
The Tomb's shape transformation of the Kings of Tanete Tomb \\ from the $17^{\text {th }}$ to the $20^{\text {th }}$ Century
}

\author{
Muhammad Nur \\ Departemen Arkeologi, Universitas Hasanuddin \\ Jl. Perintis Kemerdekaan, Km. 10, Makassar, Indonesia \\ mnur@unhas.ac.id
}

Naskah diterima: 03/05/2018; direvisi: 04/05-28/06/2018; disetujui: 20/07/2018

Publikasi ejurnal: 31/07/2018

\begin{abstract}
Our understanding of the cultural transformation phase of the Islamic grave in South Sulawesi is still limited to the study of its territorial scope, not specific to a particular locality or kingdom. This study aims to determine the stage of transformation of Islamic shape tomb in Tanete Kingdom, Barru and its causal factors. The research used artefactual data which are four complex of King Tanete tomb, interview data and historical data. The methods used are survey, interview, literature study, identification and interpretation. The study conclude three stages of transformation shape tomb at Tanete, the first transformation of the early seventeenth century characterized by tombstone, both occurring in the mid-18th century to the beginning of the nineteenth century characterized by decorative and inscribed tombs, and the third occurred beginning of the 20th century with the characteristic of European architecture. The cause of the three stages of the transformation of the tomb is the external factor, the first stage of the Gowa kingdom, the second stage of Malay culture, and the third stage is the influence of political relations with the Dutch Government.
\end{abstract}

Keyword: Transformation, Tanete, shape, tomb, cungkup.

\begin{abstract}
Abstrak
Pemahaman kita tentang fase transformasi budaya kubur Islam di Sulawesi Selatan masih terbatas pada kajian yang sifatnya wilayah, belum spesifik pada satu lokalitas atau kerajaan tertentu. Penelitian ini bertujuan mengetahui tahapan tranformasi bentuk makam Islam di Kerajaan Tanete, Barru dan faktor penyebabnya. Data yang digunakan adalah data artefaktual yaitu empat kompleks makam Raja Tanete, data wawancara dan data sejarah. Metode yang digunakan adalah survei, wawancara, studi literatur, identifikasi dan interpretasi. Penelitian ini menyimpulkan tiga tahap transformasi bentuk makam di Tanete, transformasi pertama pada awal abad ke-17 yang dicirikan oleh makam bercungkup, kedua terjadi pada pertengahan abad ke-18 hingga awal abad ke-19 yang dicirikan oleh makam dekoratif dan berinskripsi, dan ketiga terjadi awal abad ke-20 dengan ciri arsitektur Eropa. Penyebab tiga tahap transformasi bentuk makam tersebut adalah faktor eksternal, tahap pertama dari kerajaan Gowa, tahap kedua dari budaya Melayu, dan tahap ketiga adalah pengaruh hubungan politik dengan Pemerintah Belanda.
\end{abstract}

Kata Kunci: Transformasi, Tanete, bentuk, makam, cungkup.

\section{PENDAHULUAN}

Meskipun tidak pesat, kajian arkeologi kubur Islam di Sulawesi Selatan tetap mengalami kemajuan yang ditandai oleh karya Rosmawati (2013), Chalid (2013), Nur dan Hasanuddin (2017), Mulyadi dan Nur (2017), Mahmud et al.
(2007), Nur et al., (2008) dan beberapa skripsi dari Departemen Arkeologi Universitas Hasanuddin (Makassar) seperti Syamsir Bachrir (2010). Dari kajian arkeologi kubur Islam di Sulawesi Selatan tersebut, kita telah mengetahui bahwa ada tipologi nisan tertentu yang berbeda antara 
nisan Bugis, Makassar dan Mandar, pengaruh budaya Persia sangat kuat pada penampilan makam seperti yang terlihat di kompleks Makam Raja-raja Binamu, Jeneponto, sebaran nisan tipe Bugis di wilayah Makassar seperti yang terdapat di kompleks makam Mattakko, Maros, penonjolan motif hias sulur dan kaligrafi pada kompleks makam raja Turikale, perbedaan penampilan makam yang terletak di wilayah pesisir dan pedalaman, serta diaspora perantau Bugis ke Pulau Serangan (Bali) berdasarkan data arkeologi kubur Islam (Bachrir, 2010; Chalid, 2013; Mahmud, Nur, Thosibo, \& Hakim, 2007; Muhammad Ali Fadillah, 1999; Mulyadi \& Nur, 2017; Nur, Duli, \& Rukka, 2008; Nur \& Hasanuddin, 2017; Rosmawati, 2013).

Walaupun banyak kompleks makam raja-raja telah diteliti oleh sarjana setempat tetapi sesungguhnya belum ada kajian transformasi bentuk makam pada lokalitas tertentu (atau kerajaan tertentu) di Sulawesi Selatan. Dengan demikian, kajian perkembangan bentuk makam yang mengekspresikan pemahaman religiusitas masyarakat selalu ditinjau dalam skala yang luas atau skala wilayah budaya. Hal tersebut disebabkan karena kebanyakan makam kuno Islam telah rusak dan hancur sehingga perkembangan budaya kubur Islam dalam skala kerajaan sulit diketahui. Kondisi ini menjadikan pemahaman kita tentang fase perkembangan budaya kubur Islam di Sulawesi Selatan masih terbatas pada kajian yang sifatnya wilayah dan antar-situs, belum spesifik pada satu lokalitas atau kerajaan tertentu. Dalam artikel ini, akan dibahas empat kompleks makam Raja-raja Tanete (Kabupaten Barru) yang masing-masing mewakili masa pembuatannya. Meskipun banyak yang telah rusak tetapi makam pada keempat kompleks makam Raja-raja Tanete tersebut masih dapat diketahui bentuk aslinya sehingga transformasi bentuk makam masih tergambar dari abad ke-17 sampai awal abad ke-20.
Dugaan terjadinya transformasi bentuk makam di Tanete dipicu oleh data sejarah yang menunjukkan gencarnya perubahan politik di wilayah pesisir Sulawesi Selatan. Perubahan iklim politik di Sulawesi Selatan tidak hanya berimplikasi pada aspek ekonomi dan politik tetapi juga hingga aspek religi seperti bentuk makam. Perubahan aspek religi sebagai respon atas interaksi masyarakat dan bangsawan Tanete terhadap budaya luar inilah yang akan ditelusuri pada perubahan bentuk makam.

Ada dua masalah yang akan dibahas dalam artikel ini. Masalah pertama adalah tahapan transformasi bentuk makam Raja-raja Tanete. Jawaban permasalahan ini digali dari pengidentifikasian ciri khas makam untuk menggambarkan berapa kali dan kapan perubahan penampilan makam Rajaraja Tanete terjadi. Masalah kedua adalah faktor yang mempengaruhi terjadinya transformasi bentuk makam Raja-raja Tanete dari abad ke-17 hingga abad ke-20. Artikel ini akan memberi sumbangan pada kajian transformasi budaya Islam Nusantara, khususnya transformasi bentuk makam Islam.

\section{METODE PENELITIAN}

Dalam penyusunan artikel ini, paling tidak tiga kali kunjungan penulis ke kompleks makam Raja-Raja Tanete yaitu pada tahun 2012, 2015 dan 2017. Dalam tiga kali kunjungan riset tersebut, penulis mewawancarai tokoh masyarakat setempat dan keluarga bangsawan yang masih keturunan dari tokoh atau raja yang dimakamkan di keempat KM Raja-Raja Tanete. Beberapa sarjana yang pernah melakukan penelitian di lokasi tersebut juga penulis temui di Makassar untuk mendapatkan gambaran yang lebih luas tentang aspek historis dan referensi pendukung yang dapat digunakan untuk mengetahui proses Islamisasi yang terjadi di Kerajaan Tanete. Pengamatan kondisi situs wilayah inti Kerajaan Tanete dan pendokumentasian dimensi makam-makam 
kuno telah dilakukan. Tidak luput diamati dan didokumentasi detailnya adalah motif hias, inskripsi, bentuk dan tipe nisan serta bentuk makam pada keempat kompleks makam Raja-raja Tanete. Pengidentifikasian dan pengelompokan motif hias, inskripsi, bentuk dan tipe nisan serta bentuk makam diarahkan pada penentuan ciri khas tiap kompleks makam agar perbedaan penampilannya dapat diketahui. Data tekstual kemudian diintegrasikan dengan ciri khas tiap kompleks makam untuk mengetahui faktor penyebab transformasi bentuk makam Raja-raja Tanete dari abad ke-17 hingga abad ke-20.

\section{HASIL DAN PEMBAHASAN}

\section{Sejarah Singkat Kerajaan Tanete}

Pada Jaman Logam periode kedua yang berawal pada abad ke-10, kerajaankerajaan sejarah mulai bermunculan di Sulawesi Selatan (Caldwell \& Nur, 2005), termasuk di Kabupaten Barru. Populasi di Kabupaten Barru tergolong sebagai etnik Bugis (Nur, 2011). Wilayah administratif Barru berada di antara Kota Parepare di utara, Maros di selatan, Selat Makassar di barat dan Soppeng di timur. Pada masa lalu, terdapat beberapa kerajaan di wilayah Kabupaten Barru yaitu Kerajaan Nepo, Bojo, Balusu (Druce, 2009) dan Tanete. Kerajaan Tanete yang awalnya bernama kerajaan Agang Nionjo adalah satu kerajaan Bugis yang surplus pada abad ke-17 hingga awal abad ke-20. Sejarah kemunculan Kerajaan Tanete diawali oleh tokoh bernama To Sangiang yang muncul dari dunia bawah(Asba, 2010, p. 34). To Sangiang yang berhasil menyatukan rakyat Agang Nionjo kemudian memohon kepada Datu Segeri menjadi Raja Agang Nionjo. Permohonan dikabulkan dan Datu Segeri dilantik menjadi Raja Agang Nionjo dengan Gelar Datu GollaE (1552-1564). Seiring perjalanan waktu, pada masa pemerintahan Tomaburu Limanna (1597-1603), kerajaan Agang Nionjo berubah nama menjadi Kerajaan Tanete (Asba, 2010, pp. 25-26).
Tomaburu Limanna kemudian digantikan oleh Petta Pallase-lase'E (1603-1625).

Setelah Petta Pallase-lase'E, berturut-turut Kerajaan Tanete diperintah oleh Petta Matinroe Ri Bulianna (16251666), Daeng Matulung (1666-1667), La Mappajanci Daeng Mattayang (1667-1690), La Oddangriyung Daeng Matinring Sultan Yusuf Fahruddin (1733-1744) dan We Tenri Leleang (1744-1750). Anak We Tenri Leleang bernama Maddusila Tomampangewa (1750-1806) kemudian menjabat sebagai Raja Tanete lalu kemudian digantikan oleh putranya Lapatau (18061824). Karena bergerilya melakukan perlawanan kepada Belanda, istri Lapatau bernama Daeng Tanisangnga (1824-1829) kemudian menggantikannya tetapi Lapatau kembali menjadi Raja Tanete pada tahun 1829-1840 dan harus menyerahkan tampuk pimpinan Tanete kepada La Rumpang Megga (1840-1855) melalui perang yang diakhiri oleh perampasan bendera Labolong oleh Belanda yang membantu pasukan La Rumpang Megga pada tahun 1840. La Rumpang Megga kemudian mewariskan mahkota Tanete kepada cucunya We Tenri Olle (1855-1910).

Sebagai satu kerajaan berdaulat dan penting, kemuliaan darah raja-raja Tanete adalah hasil kawin mawin dengan kerajaan terpenting di Sulawesi Selatan seperti Bone, Soppeng, Luwu dan Gowa. Bukan hanya bangsawan tinggi Sulawesi Selatan, perkawinan bangsawan Tanete dengan penguasa Melayu juga menegaskan pentingnya kerajaan Tanete dalam historiografi Nusantara. Sebagai contoh, Larumpang Megga yang merupakan Raja Tanete (1840-1855) adalah keturunan campuran dari kerajaan besar Luwu, Bone, Soppeng dan Tanete. Istrinya, Colliq Pakue Jouhar Manikam Petta I Rappeq adalah cucu Ince Muhammad Ali Asdullah yang menduduki jabatan sebagai Kepala Syahbandar di Kerajaan Gowa abad ke-19 (Amir, 2016). Putri La Rumpang Megga dengan Colliq Pakue adalah Arung Pancana 


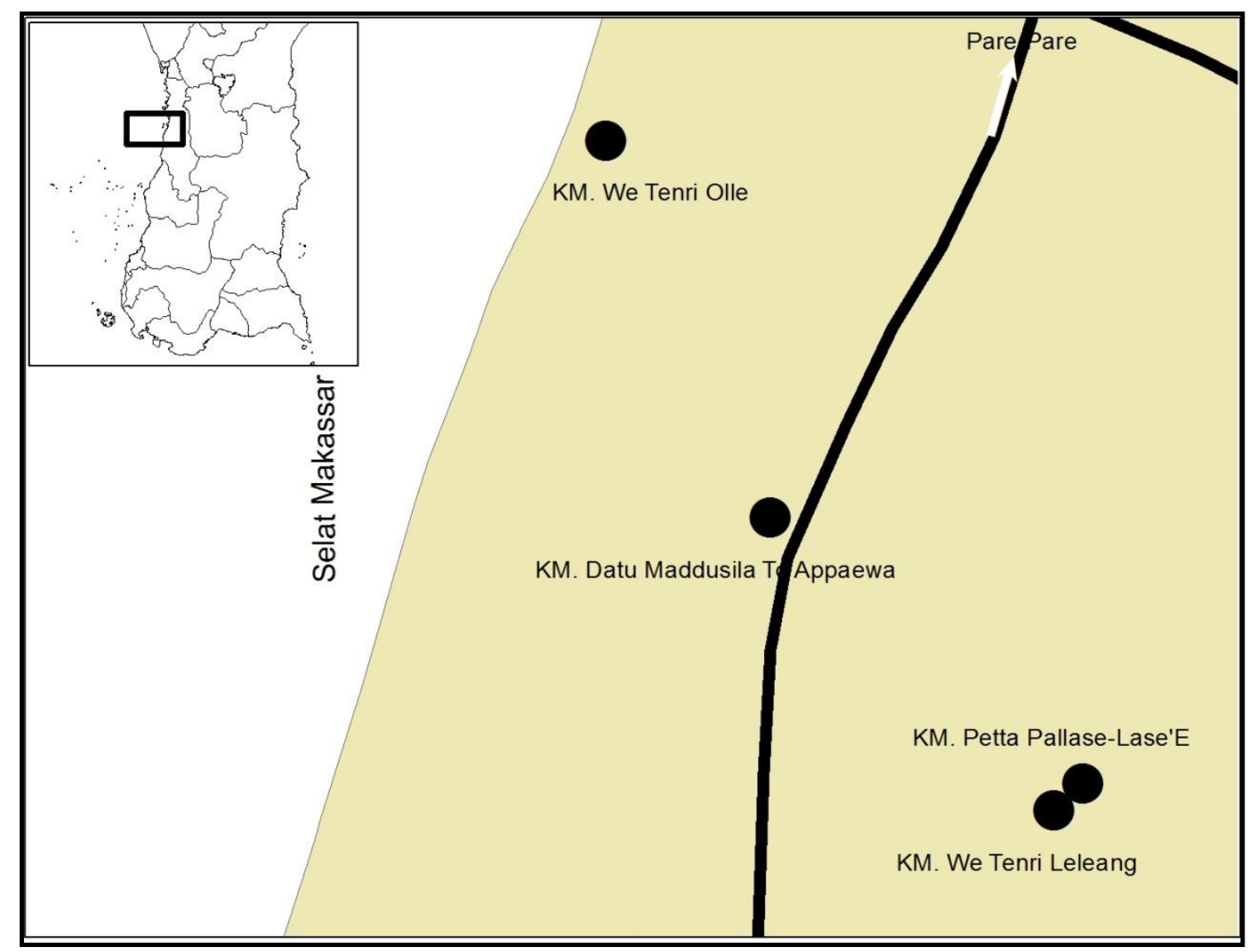

Gambar 1. Peta sebaran empat Kompleks Makam Raja-raja Tanete

(Sumber: Dokumentasi Penulis, 2018)

Toa (1812-1876) Retna Kencana Colliq Pujie yang merupakan ibu Raja Tanete We Tenri Olle (1855-1910) (Asba, 2010, p. 172; Bahrum, 2015, pp. 1-2) yang keMelayuannya jelas tergambar dari namanya.

Dalam konteks sejarah, makam Rajaraja Tanete merupakan data penting untuk historiografi lokal dan Nusantara. Raja dan tokoh yang dimakamkan pada empat makam tersebut telah mewarnai dinamika sejarah moderen Sulawesi Selatan dan Nusantara. Kerajaan Tanete sebagai bagian dari persekutuan Mallusetasi yang terdiri dari Soreang, Bacokiki, Bojo, Palanro dan Nepo adalah satu kesatuan geo-politik di Sulawesi Selatan pada masa lalu. Persekutuan ini adalah satu simpul kekuatan lain selain persekutuan besar Tellumpoccoe (Bone, Soppeng, Wajo) di wilayah geo-politik Bugis.

\section{Deskripsi Makam Raja-raja Tanete}

Lokasi keempat kompleks Makam Raja-raja Tanete mengandung tinggalan arkeologis yang mencerminkan pertumbuhan pemukiman Kerajaan Tanete. Paling tidak, komponen pemukiman yang ditemukan ketika survei lapangan adalah susunan batu yang berfungsi sebagai benteng atau pembatas wilayah (Lalabbata), kompleks makam raja dan bangsawan Tanete, fragmen tembikar, poselin, stoneware, batu pelantikan raja atau Batu Pallantikang, masjid tua dan sumur atau mata air. Makam Raja-raja Tanete terdapat pada empat lokasi yaitu Kompleks Makam (KM.) Petta Pallase-lase'E, KM. We Tenri Leleang, KM. Maddusila dan KM. We Tenri Olle (Gambar 1). Keempat KM raja Tanete tersebut akan diuraikan secara berurut dari yang tertua hingga yang terakhir. 


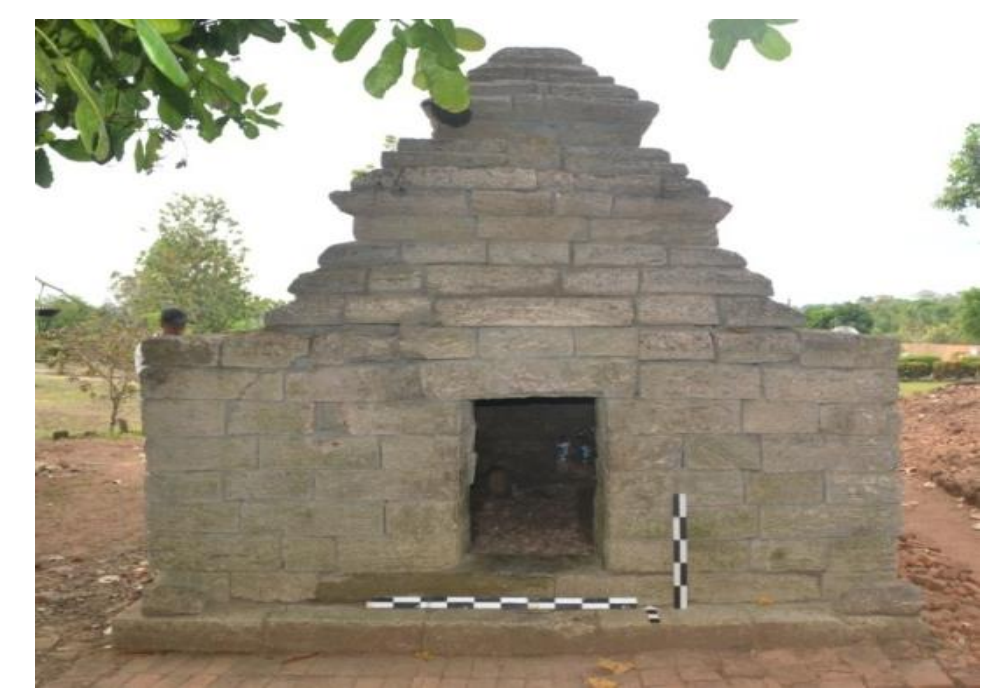

Gambar 2. Makam Petta Pallase-Lase'E, merupakan makam tunggal bercungkup (Sumber: Dokumentasi BPCB Makassar, 2017)

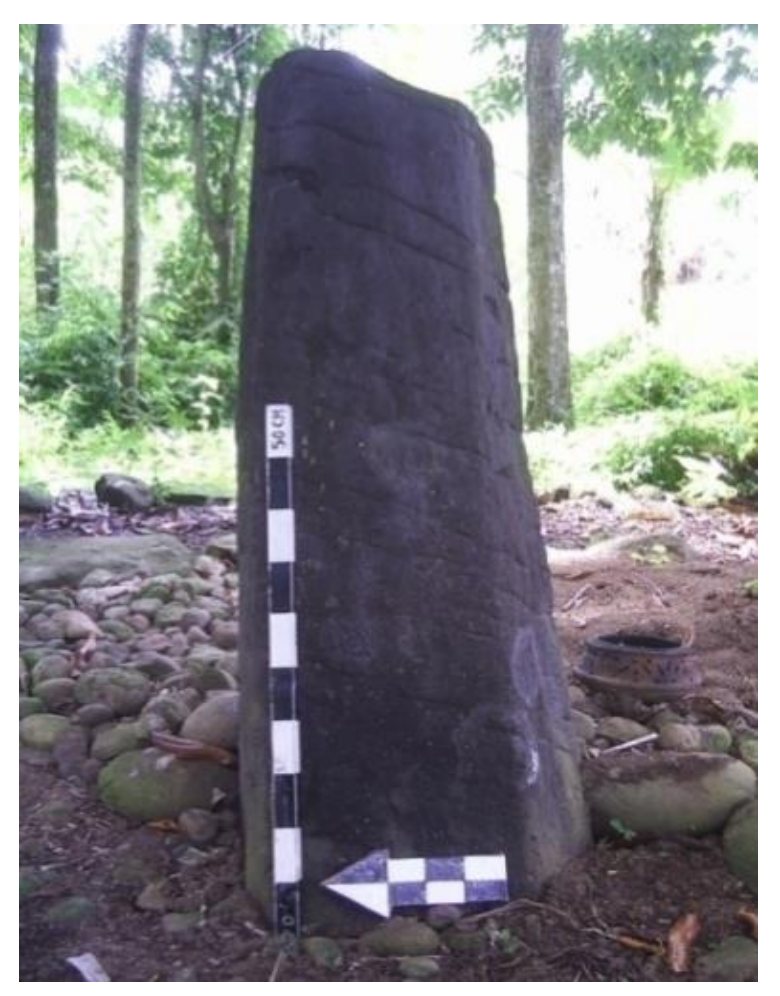

Gambar 3. Nisan batu monolit yang banyak terdapat di KM. Petta Pallase-Lase'E

(Sumber: Dokumentasi BPCB Makassar, 2017).

KM. Petta Pallase-Lase'E terletak di Jalan Langkanae, Desa Lalabata, Kecamatan Tanete Rilau. Secara astronomis terletak pada koordinat $40^{\circ} 31^{\prime} 29.5174 "$ LS dan $119^{\circ}$ 36' 27.7676" BT dengan ketinggian 40 mdpl (Tang, 2017). KM ini dikelilingi oleh kebun masyarakat, dapat dijangkau dengan kendaraan roda empat dengan jarak sekitar 1,2 km dari jalan poros Trans Sulawesi. Di sisi selatan kompleks makam ini mengalir Sungai Bungi.

Di dalam KM. Petta Pallase-Lase'E terdapat paling tidak 43 makam. Tiga makam tokoh yang dapat dilacak berdasarkan metode wawancara adalah Petta Pallase-Lase'E, Petta Bondeng dan Datu Golla. Makam Petta Pallase-Lase'E adalah makam bercungkup, menyerupai makam raja-raja Gowa di KM Sultan Hasanuddin (Kabupaten Gowa). Cungkup makam yang berongga dibentuk dari susunan batu padas segi empat tanpa perekat. Kekuatan konstruksi terdapat pada berat batuan dan beberapa kuncian pada dinding tertentu dan sudut bangunan cungkup. Cungkup makam ini (Gambar 2) memiliki 14 undakan dengan tinggi keseluruhan adalah 3 meter. Bagian dasar cungkup yang berfungsi sebagai penopang berukuran panjang $395 \mathrm{~cm}$ dan lebar $295 \mathrm{~cm}$.

Bentuk makam lainnya adalah makam dengan jirat tidak berundak berjumlah 28 makam, sedangkan makam berundak berjumlah 13 makam, terdiri dari dua sampai lima undakan (Gambar 4). Berdasarkan jenis bahan, jirat dikelompokkan menjadi empat bahan yaitu batu alami, batu bata, batu padas, dan 


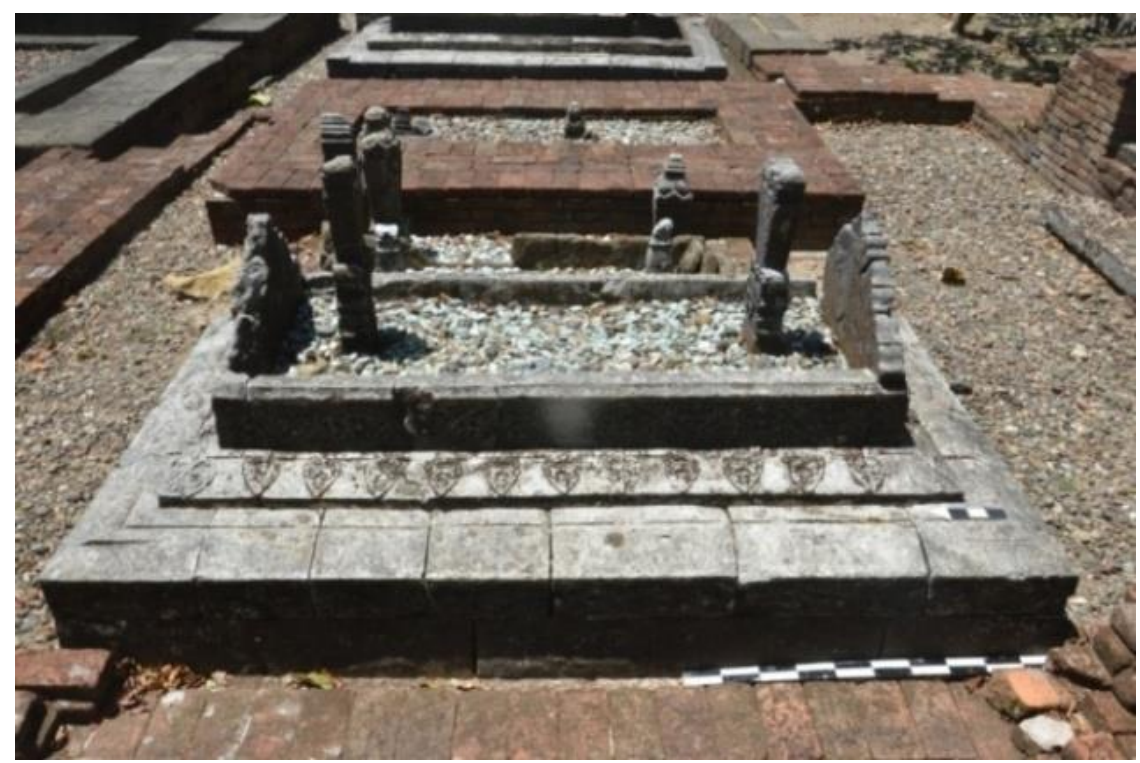

Gambar 4. Beberapa makam berundak di KM. Petta Pallase-Lase'E (Sumber: Dokumentasi BPCB Makassar, 2017)

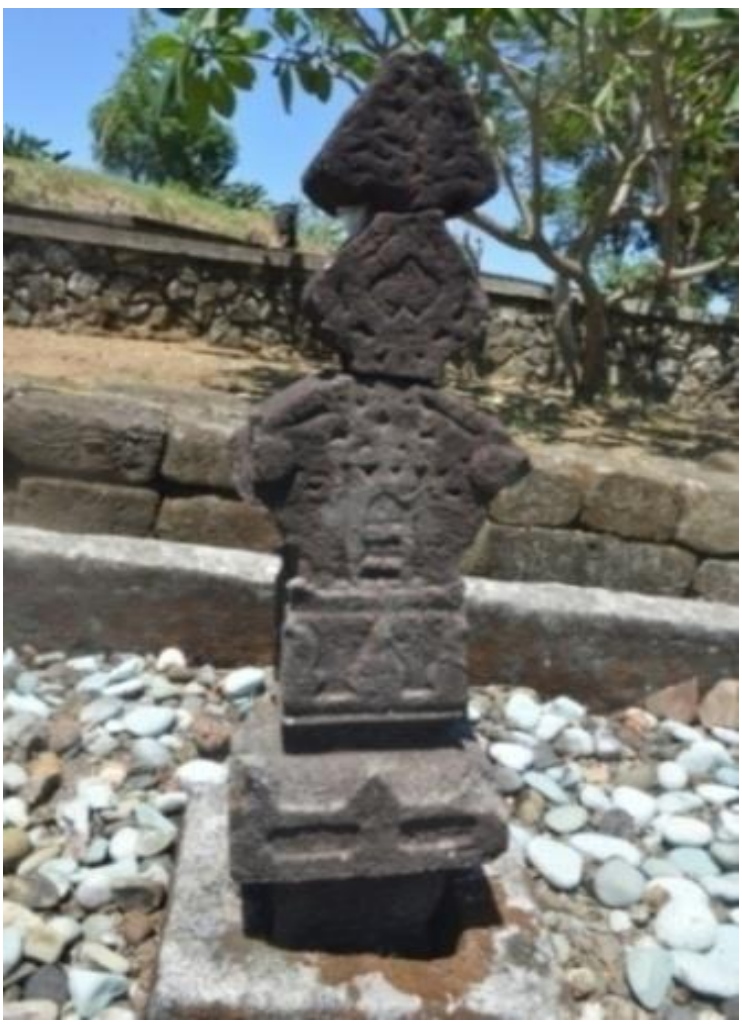

Gambar 5. Nisan Aceh tipe C di KM. Petta Pallase-Lase'E

(Sumber: Dokumentasi BPCB Makassar, 2017)

gabungan batu padas dan batu bata. Bentuk nisan adalah nisan pipih, nisan balok/pilar dan nisan batu monolit (Gambar 3). Hiasan pada makam hanya terdapat pada enam makam, dengan motif sulur, runcingan segitiga, garis lengkung beraturan, inskripsi aksara arab, lingkaran bekas mangkuk dan motif geometris. Hiasan pada makam tidak menonjol pada kompleks makam ini. Secara umum, ciri yang menonjol pada KM. Petta Pallase-Lase'E adalah makam bercungkup, nisan Aceh tipe C (Gambar 5), dan nisan batu monolit.

Kompleks Makam We Tenri Leleang terletak di Jalan Langkanae Desa Lalabata Kecamatan Tanete Rilau Kabupaten Barru, sekitar satu kilometer dari Jalan Poros Trans Sulawesi. Titik koordinat berada pada $4^{\circ} 31^{\prime}$ 22.7604" LS dan $119^{\circ} 36^{\prime} 22.9934^{\prime \prime}$ BT dengan ketinggian $21 \mathrm{mdpl}$. Dikelilingi dengan pagar keliling seluas 618,86 $\mathrm{m} 2$, kompleks makam yang mengandung 29 makam ini berbatasan dengan Masjid Laelatul Kadri di sebelah utara, serta pemukiman di sebelah timur, selatan dan barat.

Jirat makam bervariasi dan pada umumnya menggunakan balok batu padas. Ukuran makam yang paling besar adalah $166 \mathrm{~cm} \mathrm{x} 352 \mathrm{~cm}$ dan makam yang paling kecil ukuran $57 \mathrm{~cm} \times 37 \mathrm{~cm}$. Dari segi bentuk, jirat pada kompleks makam We Tenri Leleang terdiri dari dua tipe yaitu berundak (Gambar 6) dan tidak berundak. 


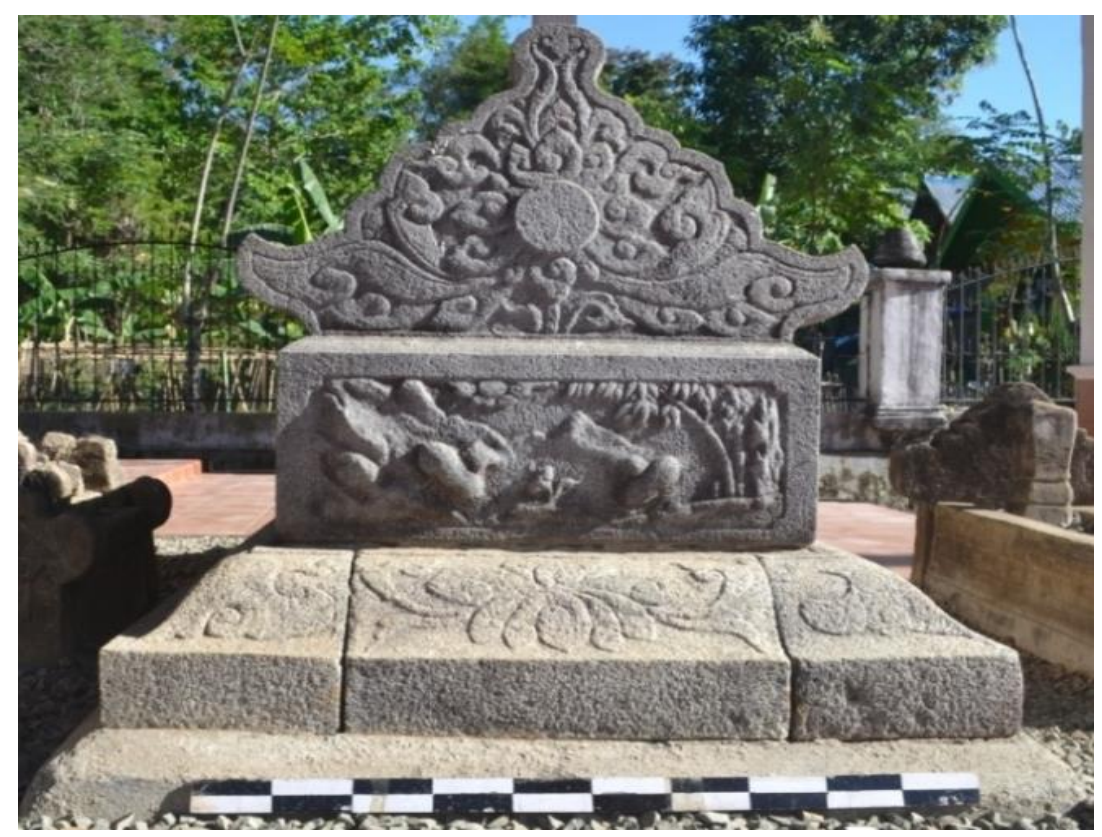

Gambar 6. Makam dengan unsur sulur, pohon dan daun di KM. We Tenri Leleang

(Sumber: Dokumentasi BPCB Makassar, 2017)

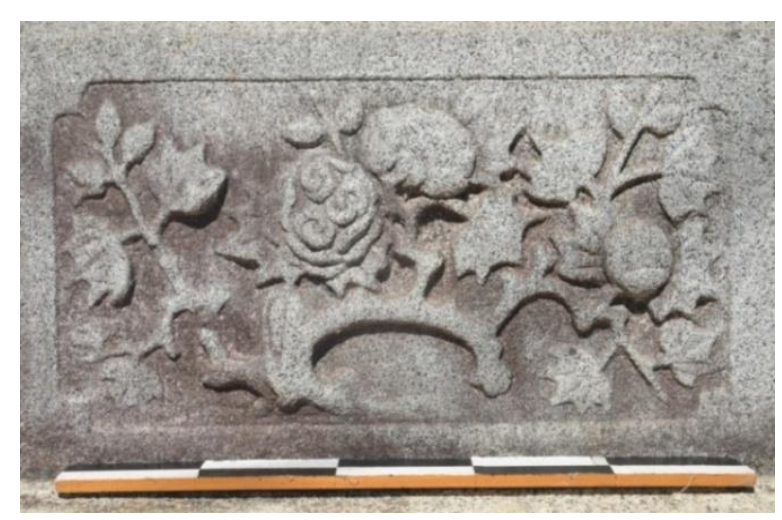

Gambar 7. Detail motif bunga dan daun di KM. We Tenri Leleang

(Sumber: Dokumentasi BPCB Makassar, 2017)

Jumlah jirat yang memiliki undakan sebanyak sembilan makam, terdiri dari dua hingga enam undakan. Nisan banyak yang berukir, memakai bahan andesit warna hitam dan putih. Bentuk nisan umumnya berbentuk pipih, balok, phallus dan mahkota.

Makam We Tenri Leleang diberi hiasan pada seluruh permukaan jirat dan nisan (Gambar 7-10). Hiasan flora yang menggabarkan sekumpulan daun dan sulursuluran, pada dinding undakan ketiga sisi utara dan selatan nampak 1 panel 2 hiasan pemandangan pohon dan objek-objek lain yang tidak dapat diidentifikasi. Bagian gunungan dipenuhi dengan sulur-suluran yang dibuat simetris, tepat di bagian tengah hiasan terdapat lingkaran yang menonjol.

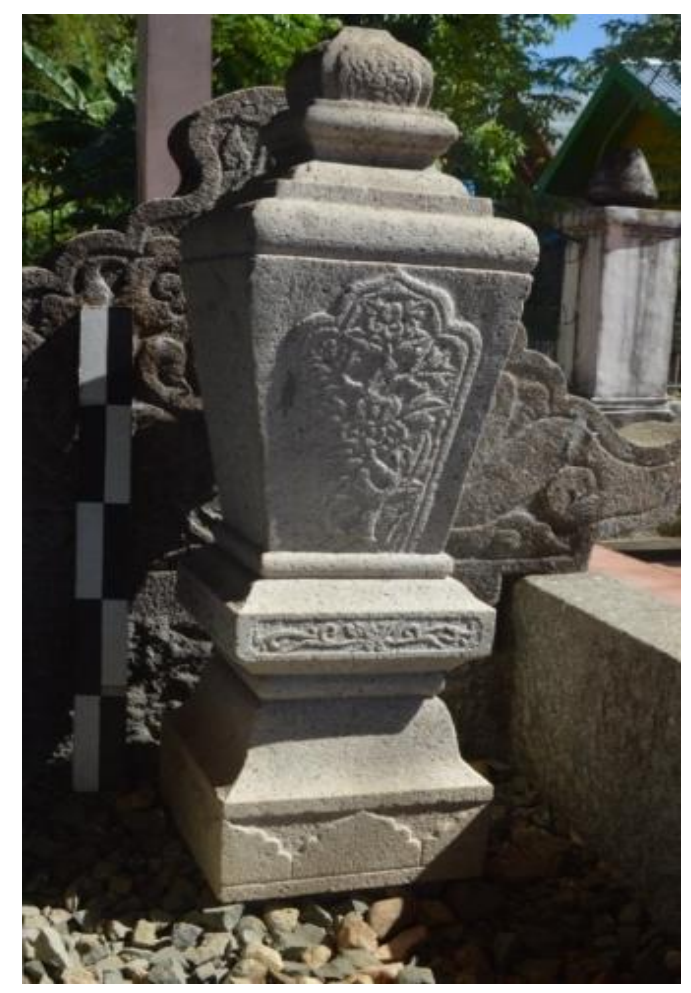

Gambar 8. Detail nisan dengan motif sulur di KM. We Tenri Leleang

(Sumber: Dokumentasi BPCB Makassar, 2017) 


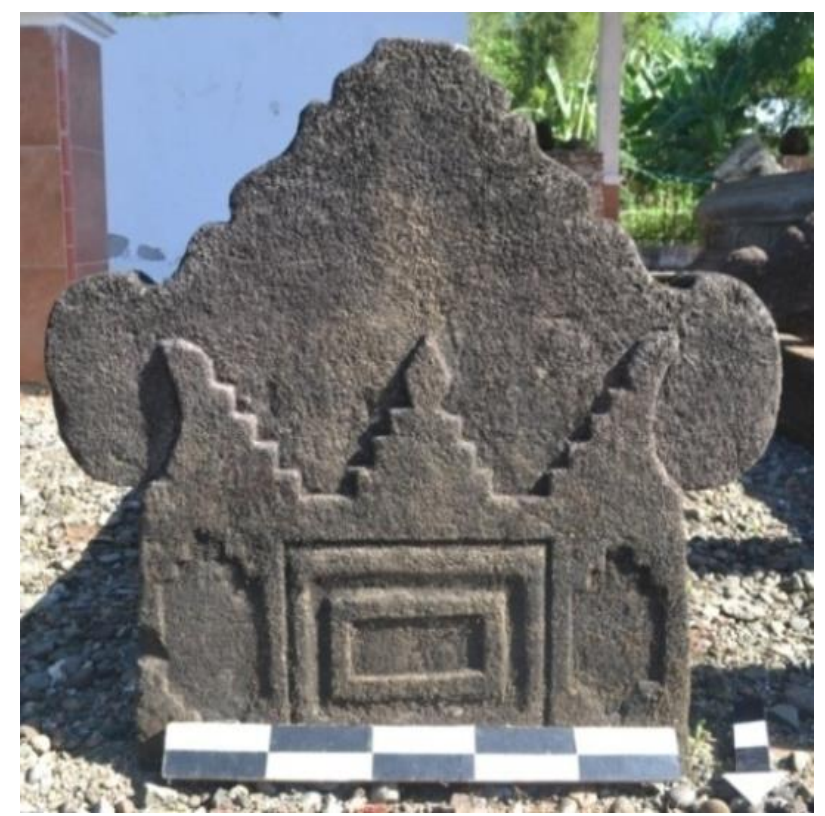

Gambar 9. Motif atap bangunan pada jirat makam di KM. We Tenri Leleang

(Sumber: Dokumentasi BPCB Makassar, 2017)

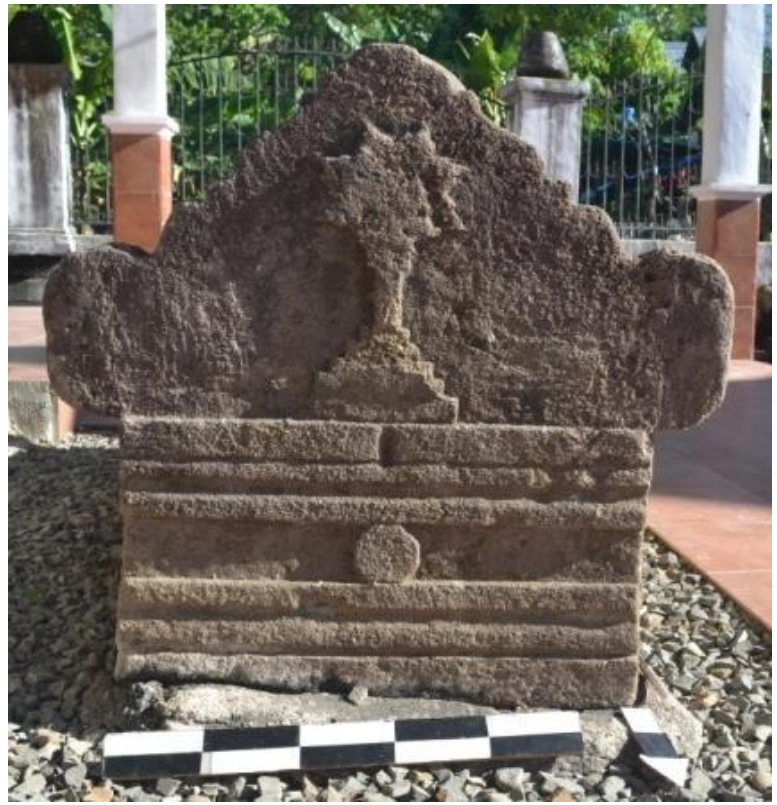

Gambar 10. Motif matahari bertangkai pada jirat makam di KM. We Tenri Leleang

(Sumber: Dokumentasi BPCB Makassar, 2017)

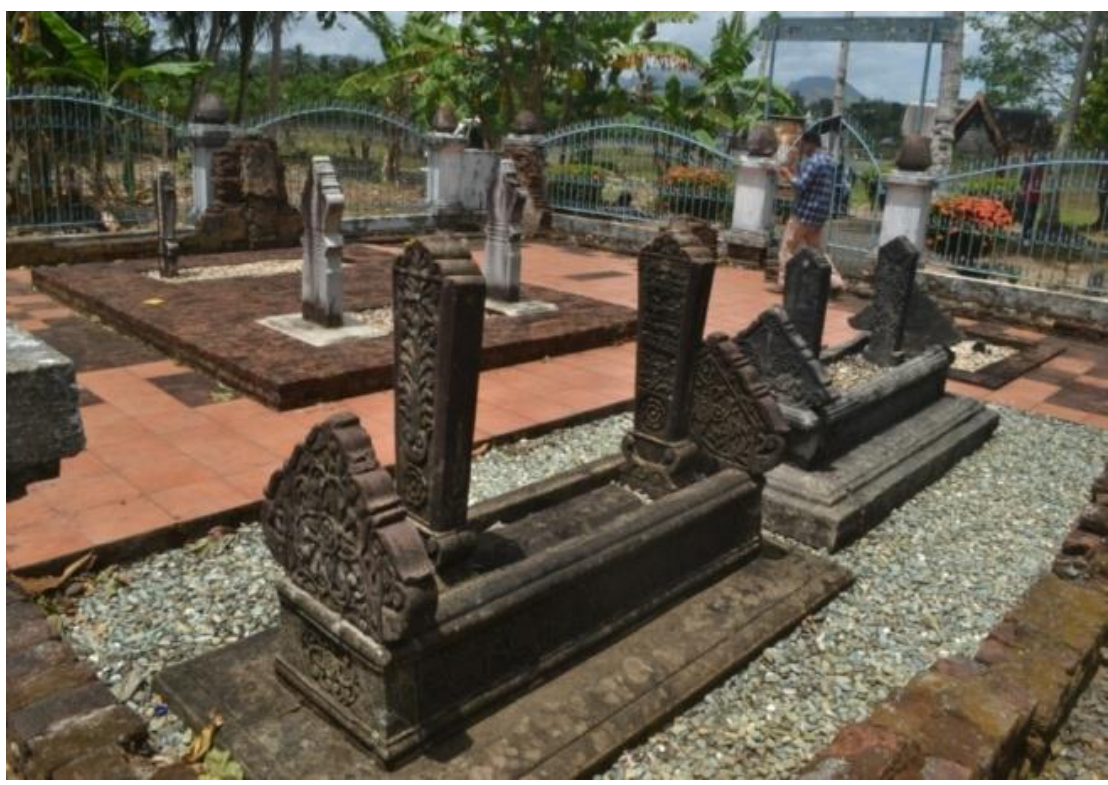

Gambar 11. Makam di KM. Maddusila

(Sumber: Dokumentasi BPCB Makassar, 2017)

Pada bagian nisan tepatnya di bagian badan terdapat bingkai hiasan yang mengikuti pola badan nisan yaitu semakin ke atas semakin melebar, puncak bingkai hiasan tersebut menyerupai kubah, dalam bingkai tersebut kemudian ditempatkan hiasan berupa sulur-suluran yang memiliki tangkai daun dan bunga pada puncaknya.
Ciri yang menonjol di KM We Tenri Leleang yang membedakan dengan ketiga kompleks makam lain di Tanete adalah motif hias yang kaya, terdiri dari motif sulursuluran, motif kubah, motif bangunan dan 


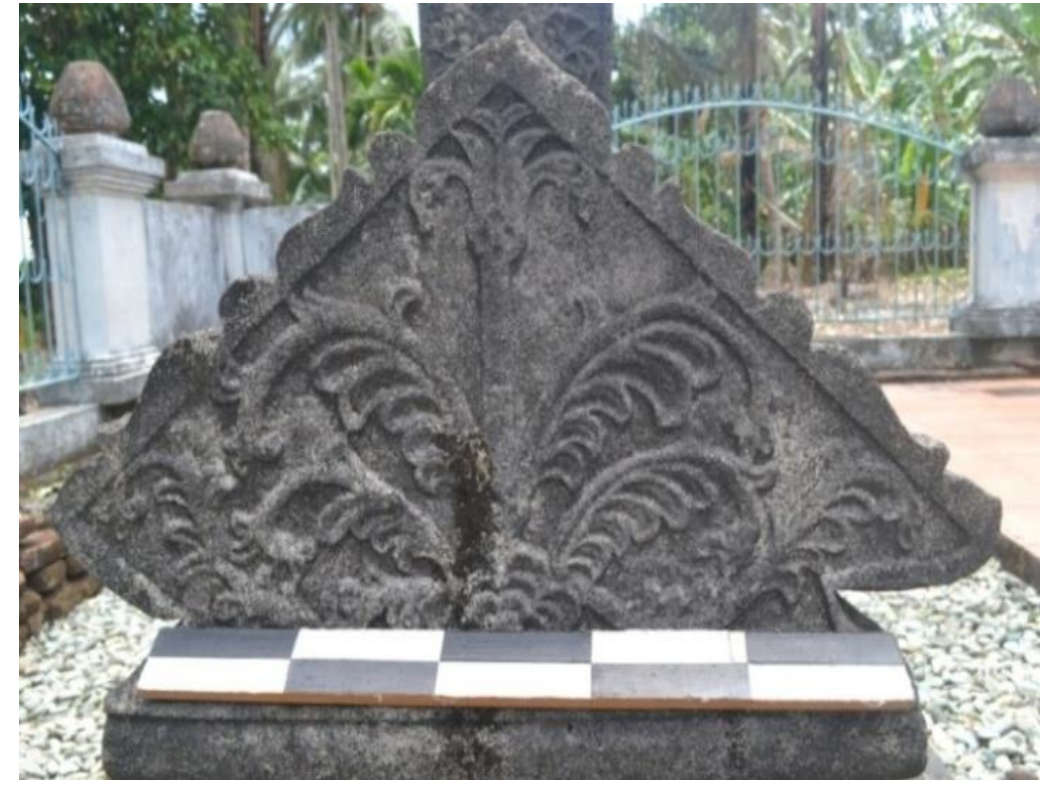

Gambar 12. Detail motif pohon pada jirat makam di KM. Maddusila (Sumber: Dokumentasi BPCB Makassar, 2017)

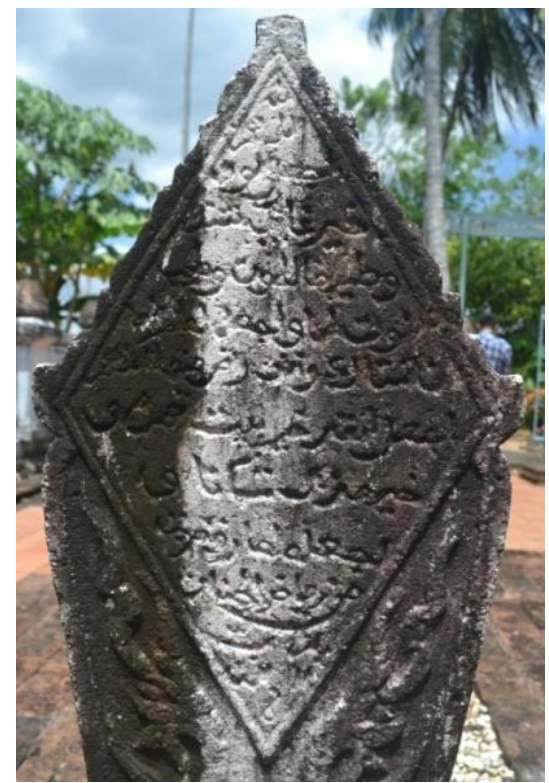

Gambar 13. Detail inskripsi Arab pada nisan di KM. Maddusila (Sumber: Dokumentasi BPCB Makassar, 2017)

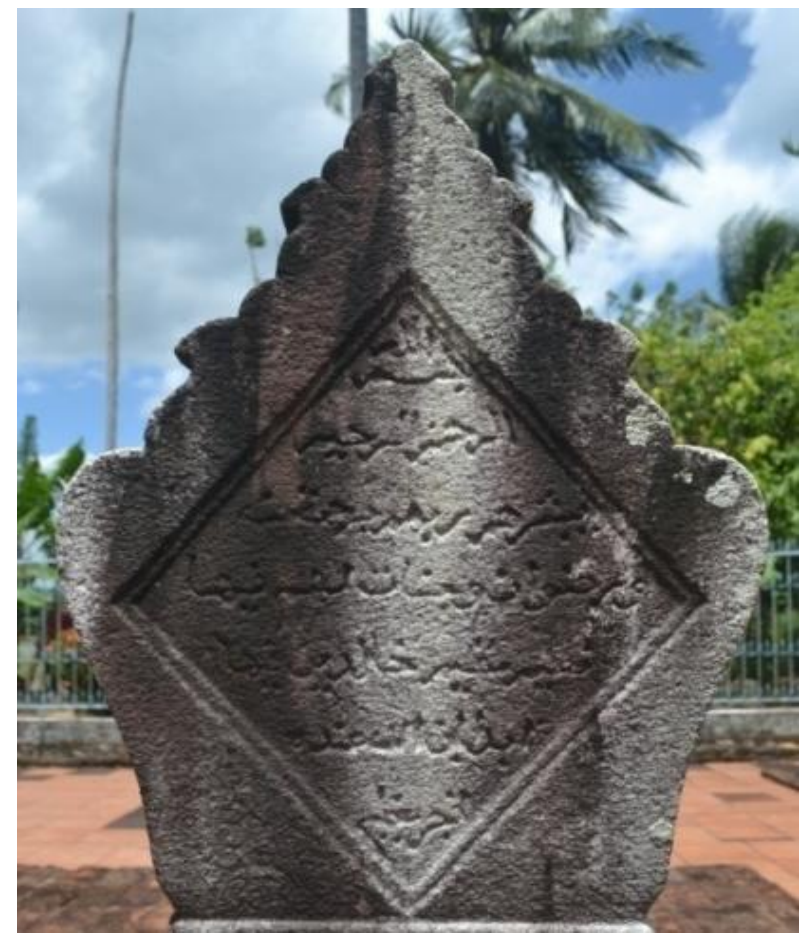

Gambar 14. Detail inskripsi Arab pada nisan di KM. Maddusila

(Sumber: Dokumentasi BPCB Makassar, 2017) motif matahari yang memakai tangkai (Gambar 10). Di antara hiasan tersebut, yang paling menonjol adalah hiasan sulursuluran.

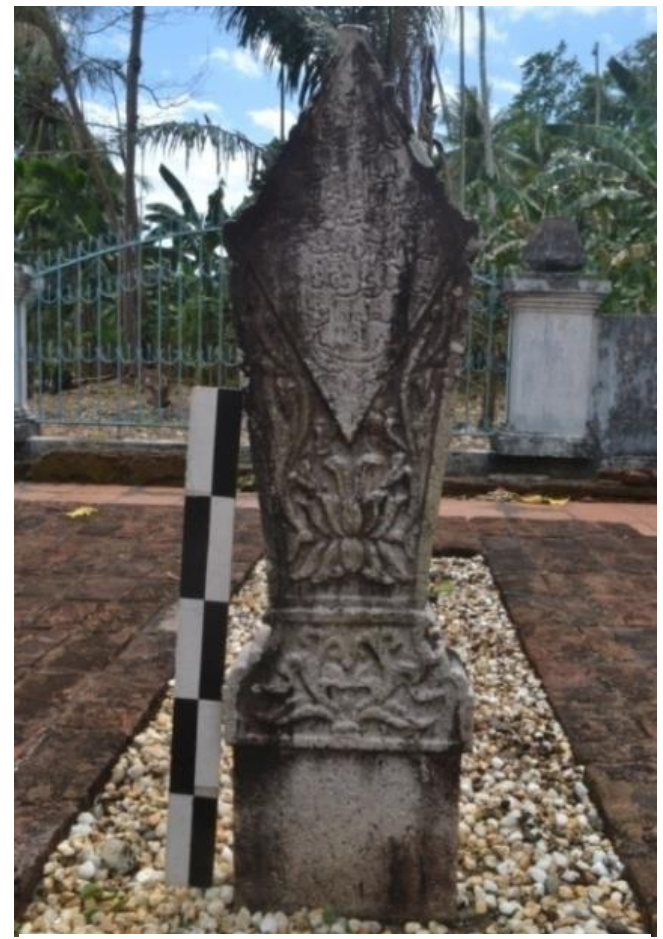

Gambar 15. Bentuk nisan pedang dengan inskripsi Arab di KM. Maddusila (Sumber: Dokumentasi BPCB Makassar, 2017)

Kompleks Makam Datu Maddusila To Appaewa (Gambar 11) terletak di Desa Pancana Kecamatan Tanete Rilau, sekitar 150 meter dari jalan poros Makassar- 


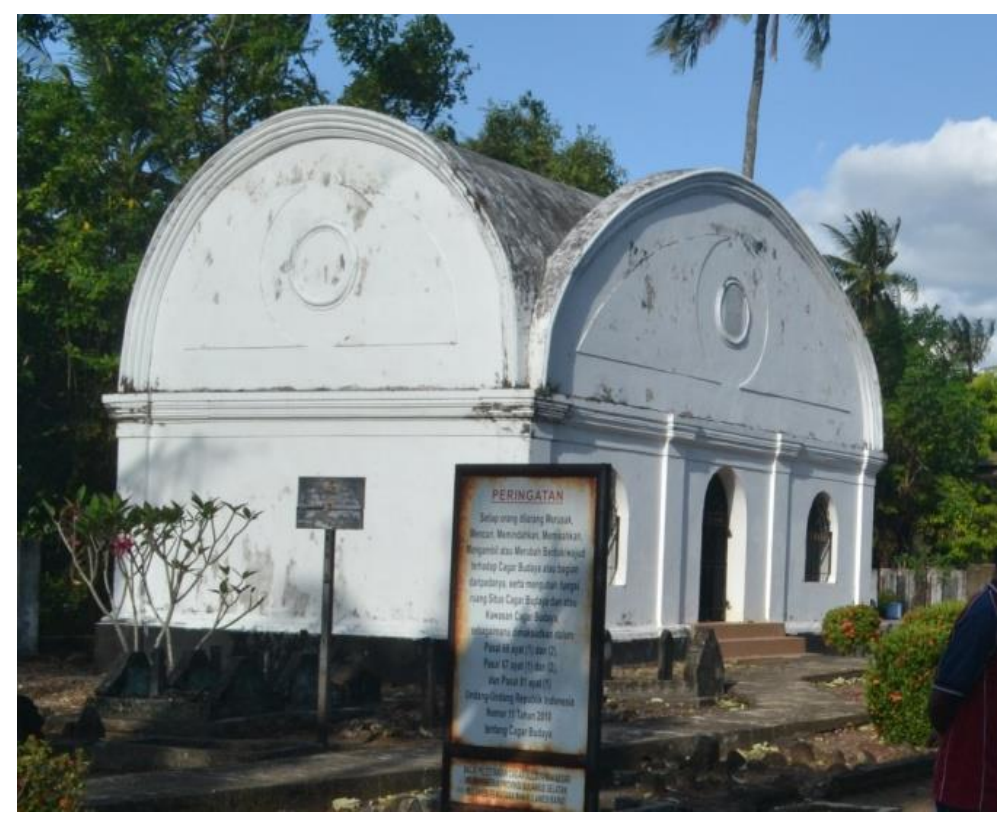

Gambar 16. Makam We Tenri Olle dengan unsur arsitektur Eropa (Sumber: Dokumentasi BPCB Makassar, 2017)

Parepare. Titik astronomis berada pada $4^{\circ}$ 32' 00.9489" LS dan $119^{\circ} 35^{\prime} 28.8216^{\prime \prime}$ BT dengan ketinggian $27 \mathrm{mdpl}$. Situs ini dikelilingi oleh tambak, sawah dan kebun masyarakat. Di dalam kompleks makam terdapat sembilan makam, lima di dalam pagar pengaman dan empat di luar besi pengaman. Terdapat sisa struktur bata yang kemungkinan merupakan sisa struktur cungkup makam, berukuran panjang 10 meter, lebar 9 meter dan tinggi 1,3 meter. Makam dalam struktur cungkup berinskripsi arab dan bermotif flora. Kelima makam berundak dua, dibentuk dari papan batu padas. Dibandingkan dengan makam pada ketiga kompleks makam lainnya, lima

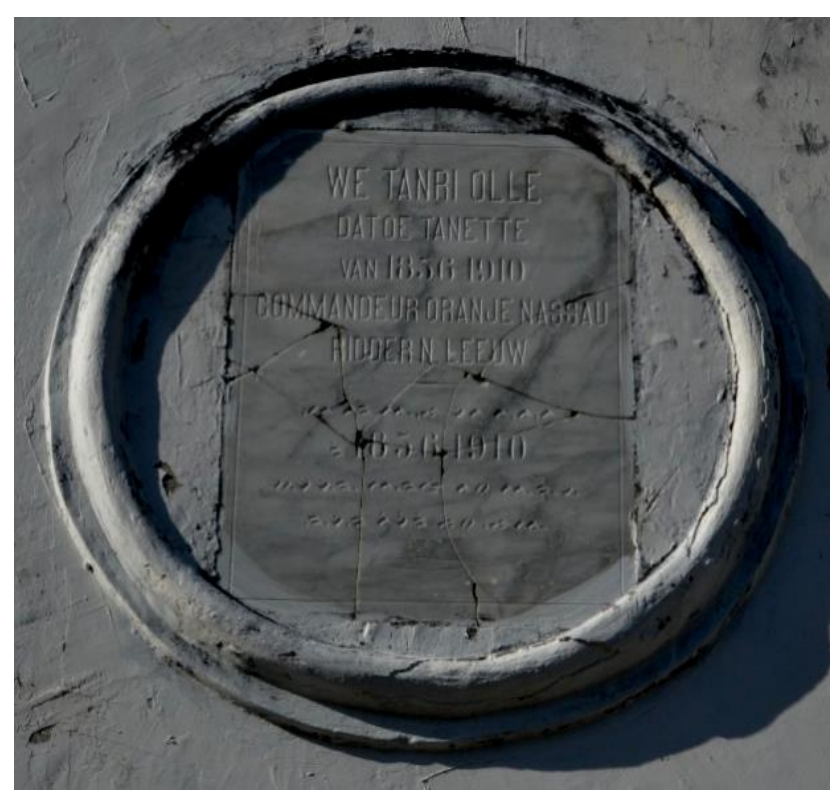

Gambar 17. Prasasti makam We Tenri Olle yang menggunakan aksara latin berbahasa Belanda dan aksara Lontara berbahasa Bugis

(Sumber: Dokumentasi BPCB Makassar, 2017) 
makam di kompleks makam Maddusila yang paling dekoratif. Dekorasi makam terdapat pada semua sisi jirat dan nisan, terdiri dari motif pohon, daun (Gambar 12), sulur, bunga, inskripsi Arab (Gambar 13 dan 14). Di antara motif hias yang ada, yang paling menonjol adalah motif inskripsi Arab. Tipe nisan yang menonjol adalah tipe pedang (Gambar 15).

Kompleks Makam We Tenri Olle terletak di Jl. We Tenri Olle, Pancana Desa Pancana Kecamatan Tanete Rilau. Titik astronimis berada pada $4^{\circ} 31^{\prime} 36.6748^{\prime \prime} \mathrm{LS}$ dan $119^{\circ} 34^{\prime} 58.4026^{\prime \prime}$ BT dengan ketinggian 9 mdpl. Kompleks makam ini dibatasi oleh pemukiman di pada semua sisi kecuali di sebelah timur yang berbatasan dengan masjid Al Muttaqaddimin. Makam di kompleks ini dapat dibagi dua macam, yaitu makam kolektif bercungkup dan tidak bercungkup. Makam kolektif bercungkup ada dua dan yang tidak bercungkup berjumlah 328 makam yang telah bercampur dengan makam baru. Ciri makam Raja Tanete yang paling menonjol adalah Makam We Tenri Olle (Gambar 16) yang dicirikan oleh bentuk cungkup kubah (dome). Bentuk denah persegi panjang, berorientasi $208^{\circ}$, berciri aksitektur Eropa dengan bentuk atap setengah lingkaran mirip rumah kodok (queenhut) Pada bagian depan terdapat prasasti menggunakan bahasa Belanda dan aksara lontara (Gambar 17). Lantai bagian dalam cungkup adalah tegel berwarna cokelat dan terdapat sebuah pilar berbentuk persegi. Di dalam cungkup terdapat lima makam termasuk makam We Tenri Olle (Tang, 2017).

\section{Transformasi Bentuk Makam dari abad ke-17 hingga abad ke-18}

Dalam aturan Islam, terdapat larangan penggunaan bangunan di atas kubur. Larangan pembuatan bangunan sebenarnya dimaksudkan sebagai penyamaan status si mati di depan penciptanya. Dalam pandangan Islam, gejala tersebut dapat saja dikatakan sebagai penyimpangan (distortion), tetapi dalam pandangan kebudayaan, gejala penggunaan bangunan di atas kubur seperti jirat semu atau cungkup adalah hal yang wajar. Di sinilah diskusi tentang transformasi bentuk makam Islam mendapat ruang, ketika dipandang dalam perspektif kebudayaan. Dalam perspektif ini, makam dianggap mengandung unsur keduniawian (kemegahan dan status) dan unsur kebangkitan setelah kematian.

Transformasi bentuk makam Islam di Kerajaan Tanete menunjukkan beberapa faktor yang menjadi penyebab. Faktor eksternal akibat hubungan dengan daerah atau pranata luar memperlihatkan pengaruh kuat terhadap transformasi bentuk makam raja-raja Tanete. Semakin tingginya intensitas kontak budaya pada jaman Sejarah Moderen adalah satu penjelasan kunci tentang transformasi bentuk makam di Tanete. Perubahan penampilan bentuk makam dari abad ke-17 hingga abad ke-20 adalah ekspresi dari semakin intensifnya hubungan budaya Tanete dengan kerajaan atau pranata lain, baik di Sulawesi maupun di luar Sulawesi.

Penjelasan tentang gejala transformasi bentuk makam Raja-raja Tanete akan dimulai dari abad ke-17. Dari segi tipologi makam, ada tiga tahap perkembangan bentuk makam dari abad ke17 hingga abad ke-20 yang menggambarkan hubungan politik Tanete dengan kerajaan atau pranata lain dari luar kerajaan Tanete. Kompleks makam Petta Pallase-lase'E (1603-1625) merupakan tahap pertama, memperlihatkan ciri makam yang lebih monumental seperti terlihat pada makam yang memakai cungkup (Gambar 2) dan penggunaan nisan Aceh yang sangat tipologik. Sebelum penggunaan cungkup dan nisan Aceh, makam dengan batu monolit (menhir) adalah ciri khas tanda kubur pada periode sebelum Islam melembaga di Tanete, dimana unsur megalitis masih sangat kuat. Perubahan bentuk tanda kubur dari batu monolit (Duli \& Nur, 2016; 
Hasanuddin, 2011) menjadi makam bercungkup, makam berundak dan penggunaan nisan Aceh adalah penanda transformasi bentuk makam tahap pertama di Kerajaan Tanete.

Walaupun hanya satu makam tunggal tipe cungkup yaitu makam Petta Pallase-lase'E tetapi dapat memberikan informasi penting tentang kesejajarannya dari segi waktu dan bentuk dengan makam raja lain seperti makam Sultan Alauddin dan Sultan Hasanuddin di Gowa. Makam tunggal tipe cungkup berkembang pesat dan menjadi kecenderungan (trend) pada abad ke-17 di istana kerajaan penting di Sulawesi Selatan seperti di Kerajaan Gowa, Tallo, Lamuru, Luwu, dan Bantaeng. Pemakaian cungkup pada makam tunggal menunjukkan kesetaraan Tanete dengan kerajaan penting di Sulawesi Selatan. Meskipun makam tunggal bercungkup adalah ekspresi pemahaman tentang kematian tetapi bentuk cungkup pada makam Petta Pallase-lase'E dipengaruhi oleh faktor politis. Kerajaan Gowa (kekuatan paling besar di Nusantara pada awal abad ke-17) sebagai kerajaan yang dikiprahi oleh Kerajaan Tanete telah memberikan pengaruh sampai pada aspek penguburan. Dalam cara pandang ini, kemegahan atau status sosial si mati (Petta Pallase-lase'E) diekspresikan dalam bentuk makam tunggal bercungkup seperti yang menjadi kecenderungan di Sulawesi Selatan termasuk makam Raja-raja Gowa. Status kerajaan Tanete sebagai kerajaan bawahan dari kerajaan Gowa adalah jawaban kunci dari persamaan bentuk makam tunggal bercungkup di Tanete dan Gowa.

Selain makam tunggal bercungkup, salah satu makam di KM. Petta Pallaselase'E juga memakai nisan Aceh tipe C. Berdasarkan data bandingan, tipe tersebut berkembang di Aceh pada abad ke16. Keberadaan nisan Aceh tipe $\mathrm{C}$ adalah gambaran dari keterlibatan Tanete dalam historiografi Nusantara pada abad ke-17. Nisan Aceh diproduksi sejak awal abad ke15 sampai abad ke-19, dengan jumlah 14 tipe, dimana tipe-tipe tersebut mewakili periode perkembangan (Yatim, 1987). Nisan Aceh dibuat untuk memperindah makam, dengan segala simbol dan pemaknaan di dalamnya. Biasanya, dipakai sebagai tanda kubur raja atau keluarga kerajaan, bangsawan, kepala kampung atau orang kaya. Di Malaysia, nisan Aceh banyak dipakai oleh raja-raja Melayu (Mohamed, Mat, Mutalib, Rahman, \& Arshad, 2008). Keberadaan nisan Aceh di KM. Petta Pallase-lase'E adalah simbol penyetaraan kerajaan Tanete dengan kerajaan terkemuka lain di Asia Tenggara seperti kerajaan Samudra Pasai atau kerajaan-kerajaan Melayu di Malaysia. keberadaan nisan Aceh tipe $\mathrm{C}$ yang masa perkembangannya berlangsung pada abad ke-16 adalah data artefak yang dapat digunakan untuk menjelaskan hubungan budaya yang terjadi pada kerajaan-kerajaan Islam Asia Tenggara.

Tahap kedua diwakili oleh makammakam yang terdapat pada dua lokasi yaitu KM. We Tenri Leleang dan KM. Maddusila. Makam di dalam KM. We Tenri Leleang dicirikan oleh jirat ornamental dengan penonjolan pada hiasan sulur-suluran, sedangkan di KM. Maddusila, makamnya dicirikan oleh penonjolan kaligrafi Arab dengan kalimat-kalimat tauhid yang dipahat secara detail dan cermat. Transformasi bentuk makam tampak jelas dari bentuk yang monumental seperti yang ditunjukkan pada KM. Petta Pallase-lase'E menjadi makam yang sangat ornamental seperti yang ditunjukkan dalam makam di KM. We Tenri Leleang dan KM. Maddusila. Seni pahat sangat ditonjolkan pada transformasi tahap kedua sehingga sangat mengekpresikan nilai-nilai simbolik yang lebih kuat.

Transformasi tahap ketiga kembali terjadi pada awal abad ke-20 seperti diekspresikan oleh KM. We Tenri Olle yang dicirikan oleh makam kolektif yang memakai cungkup dengan bentuk atap dome berciri arsitektur Eropa (Belanda). Bentuk atapnya melengkung diikuti oleh bentuk 
atasan jendela dan pintu yang juga melengkung. Pengaruh arsitektur Eropa sangat kuat seperti terlihat pada bentuk atap, pintu dan jendela kubah makam. Jika dihubungkan dengan data sejarah, bentuk kubah makam We Tenri Olle yang menggunakan gaya arsitektur Eropa adalah wujud dari kuatnya persahabatan antara We Tenri Olle dengan pemerintah Belanda. Pemakaian kubah pada makam raja atau pemuka Islam adalah kecenderungan (trend) pada abad ke-19 hingga awal abad ke-20 di Sulawesi Selatan seperti yang terdapat di Kompleks Makam Lajangiru di Bontoala (Makassar) dan kompleks Makam Katangka (Gowa). Prasasti makam We Tenri Olle yang memakai aksara Latin berbahasa Belanda dan aksara Bugis berbahasa Bugis menegaskan hubungan politik Tanete dengan pemerintah Belanda yang sangat erat pada masa pemerintahan We Tenri Olle.

\section{PENUTUP}

Ada dua kesimpulan yang dihasilkan sesuai dengan pertanyaan penelitian yang diajukan pada bagian awal, pertama adalah transformasi bentuk makam Raja-raja Tanete dari abad ke-17 hingga abad ke-20 minimal terjadi tiga kali jika didasarkan pada data empat kompleks makam yang telah diurakan. Transformasi pertama terjadi dari bentuk kubur dengan penanda batu monolit (menhir) menjadi makam tunggal bercungkup dan penggunaan nisan Aceh tipe C, seperti yang terdapat di KM. Petta Pallase-Lase'E. Transformasi tahap pertama terjadi pada abad ke-17 dengan ciri bentuk makam yang monumental. Transformasi tahap kedua terjadi pada pertengahan abad ke-18 hingga awal abad ke-19, dimana bentuk makam lebih ornamental yang mengekspresikan motif bunga, tanaman dan inskripsi Arab. Transformasi tahap kedua jelas terlihat pada KM. We Tenri Leleang dan KM. Maddusila. Transformasi tahap ketiga terjadi pada awal abad ke-20, dicirikan oleh penggunaan cungkup makam berbentuk dome yang bentuknya mengingatkan kita pada bentuk bangunan rumah kodok (queenhut).

Kesimpulan kedua adalah transformasi bentuk makam di Tanete terjadi tiga kali yang semuanya disebabkan oleh faktor dari luar Kerajaan Tanete. Transformasi tahap pertama adalah pengaruh Kerajaan Gowa, transformasi tahap kedua adalah pengaruh budaya Melayu, dan transformasi tahap ketiga adalah akibat hubungan politik dengan Pemerintah Belanda.

\section{Ucapan Terima kasih}

Terima kasih kepada bapak Drs. Laode M. Aksa, M.A. selaku kepala BPCB Makassar yang telah melibatkan saya dalam proyek Zonasi Kompleks Makam Raja-Raja Tanete Barru tahun 2017. Selain itu, juga dihaturkan terima kasih kepada rekan-rekan di lapangan terutama kepada bapak Khaeruddin, $\mathbf{M}$. Tang, Iswadi, Imran Ilyas. Dalam penyusunan artikel, saya dibantu mengidentifikasi beberapa tipe nisan oleh Dr. Rosmawati dan mengidentifikasi inskripsi dan aksara Arab makam oleh Dr. Bahar Akkase. Kepada kedua pakar tersebut saya berterima kasih.

\section{DAFTAR PUSTAKA}

Asba, A. R. (2010). Gerakan Sosial di Tanah Bugis: Raja Tanete Lapatau Menantang Belanda. Yogyakarta: Penerbit Ombak.

Bachrir, S. (2010). Perbandingan Bentuk dan Ragam Hias Nisan Makam Islam pada Wilayah Pesisir dan Wilayah Pedalaman di Sulawesi Selatan. Universitas Hasanuddin.

Bahrum, S. (2015). Mengasah Pena di Langit Biru, Mengisahkan Retna Kencana Cplliq Pujie, 
Arung Pancana Toa [1812-1876]. Makassar: Penerbit Baruga Nusantara.

Caldwell, I., \& Nur, M. (2005). Three locally-made bronzes from South Sulawesi, Possible evidence of cultural transfer from Java about AD 1000. Review of Indonesian and Malaysian Affairs, 39(1), 23-34.

Chalid, A. (2013). Bentuk-Bentuk Pengaruh Kebudayaan Persia di Sulawesi Selatan: Kajian Arkeologi Islam. Universitas Hasanuddin.

Druce, S. (2009). The lands West of the Lake: A History of the Ajattappereng kingdoms of South Sulawesi 1200 to 1600 CE. Leiden: Koninklijk Instituut voor Tall-, Land-en Volkenkunde.

Duli, A., \& Nur, M. (2016). Prasejarah Sulawesi. Makassar: FIB Press.

Hasanuddin. (2011). Megalithic sites in the district of Sinjai, South Sulawesi, Indonesia. Bulletin of the Indo-Pacific Prehistory Associationndo-Pacific Prehistory Association, 31, 76-84.

Mahmud, M. I., Nur, M., Thosibo, A., \& Hakim, B. (2007). Bantaeng : Masa Prasejarah ke Masa Islam. Makassar: Yayasan Masagena.

Mohamed, A., Mat, F. H. B., Mutalib, S., Rahman, S. A., \& Arshad, N. H. (2008). Batu Aceh Typology Identification Using Back Propagation Algorithm. Faculty of Information Technology \& Quantitative Sciences. Selangor: Universiti Teknologi MARA.

Muhammad Ali Fadillah. (1999). Warisan Budaya Bugis Di Pesisir Selatan Denpasar. Nuansa Islam Di Bali. Jakarta: Depertemen Pendidikan dan Kebudayaan, Pusat Penelitian Arkeologi Nasional.

Mulyadi, Y., \& Nur, M. (2017). Ragam Hias pada Makam di Komplek Mesjid Makam Turikale di Maros Sulawesi Selatan. Kalpataru, 26(1), 27-36.

Nur, M. (2011). Dari Hand Stencil ke Hand Print: Bukti Kontak Budaya Dengan Leluhur Orang Bugis. Walennae, 13(1).

Nur, M., Duli, A., \& Rukka, R. M. (2008). Jejak Sejarah Jeneponto. Makassar: Masagena Press.

Nur, M., \& Hasanuddin. (2017). Unsur budaya Prasejarah dan Tipo-kronologi Nisan di Kompleks Makam Mattakko, Maros, Sulawesi Selatan. Arkeologi Papua, 9(1), 5970.

Rosmawati. (2013). Perkembangan Tamaddun Islam di Sulawesi Selatan, Indonesia: Perspektif Arkeologi dan Sejarah. University Sains Malaysia.

Tang, M. (2017). Kajian Zonasi Makam-Makam Islam di Kabupaten Barru. Makassar.

Yatim, M. O. (1987). Batu Aceh: Early Islamic gravestones in Peninsular Malaysia. Kuala Lumpur: United Selangor Press. 